\title{
TINJAUAN YURIDIS PELAKSANAAN PERLINDUNGAN HUKUM BAGI KONSUMEN TERHADAP MAKANAN MIE INSTAN DALAM KEMASAN YANG TELAH KADALUWARSA
}

\author{
Jinner Sidauruk ${ }^{1}$, Nova Sari Simanjuntak ${ }^{2}$ \\ ${ }^{1}$ Program Studi Ilmu Hukum \\ Universitas HKBP Nommensen, Medan-Sumatera Utara-Indonesia \\ e-mail: jinner.sidauruk@uhn.ac.id
}

\begin{abstract}
The Research is motivated to see how The development of economic sector trade produce various types of goods or variations of food. But in the circulation of food in Indonesian special its instants noodles is still a matter to be considered, where consumers are often harmed by violations committed by business actors by selling instants noodles that have expired. Global competition makes business actors justify any means to reap the benefits of one of them by distributing food expired so that they can reduce the number of losses. Writing method used in this journal writing empirical juridical method that essentially examines the law in its application in public life. The hallmark of empirical juridical research is a study that goes from the das sollen gap (theory)to the das sein (practice or reality). The result of this research is Legal protection for consumers related to the circulation of instant noodles expired in Denpasar is worth noting where many consumers not only inDenpasar city feel the loss due to food or beverage expired. With the existence of Law No. 8 of 1999 on Consumer Protection, the guaranteed consumers who feel aggrieved and the Food and Drug Supervisory Agency in his duties only become a medium in coaching for business actors or producers who sell goods or foods that are expired, while in cracking down in the implementation of public health Office. Not only provide guidance, drug and food regulatory agencies can provide recommendations for follw-up by the health service, as well as the consumer community should be more careful in buying food and if they find naughty business actors in terms of selling expired foods can report to the agency drug and food superintendent.
\end{abstract}

Keywords: Legal Protection, Consumer, Expired

\begin{abstract}
Abstrak
Penelitian ini dilatar belakangi untuk melihat bagimana Perkembangan sektor ekonomi khususnya perdagangan menghasilkan berbagai jenis barang atau variasi makanan. Tetapi dalam peredaran makakanan di Indonesia khususnya mie instan masih menjadi hal yang harus diperhatikan, dimana konsumen sering kali dirugikan dengan pelanggaran yang dilakukan oleh pelaku usaha dengan menjual mie instan yang sudah kadaluwarsa. Persaingan global membuat pelaku usaha menghalalkan segala cara untuk meraup keuntungan salah satunya dengan cara mengedarkan makanan kadaluwarsa sehingga mereka dapat menekan angka kerugian. Metode penulisan yang digunakan dalam penulisan jurnal ini menggunakan metode yuridis empiris yang pada hakekatnya meneliti hukum dalam dalam penerapannya di kehidupan masyarakat. Ciri dari penelitian yuridis empiris adalah suatu penelitian yang beranjak dari kesenjangan das sollen (teori) dengan das sein (praktek atau kenyataan). Hasil dari penelitian ini adalah Perlindungan hukum bagi konsumen terkait peredaran mie instan kadaluwarsa di kota Pekanbaru memang perlu diperhatikan dimana banyak konsumen tidak hanya di kota Pekanbaru merasakan kerugian akibat makanan atau minuman kadaluwarsa.
\end{abstract}


Dengan adanya Undang-Undang Nomor 8 Tahun 1999 Tentang Perlindungan Konsumen maka terjaminnya konsumen yang merasa dirugikan serta Badan Pengawas Obat dan Makanan dalam tugasnya hanya menjadi media dalam pembinaan bagi pelaku usaha atau produsen yang menjual barang atau makanan yang kadaluwarsa, sedangkan dalam menindak dalam pelaksanaannya yaitu dinas kesehatan. Tidak hanya memberikan binaan, badan pengawas obat, dan makanan dapat memberikan rekomendasi agar ditindak lanjuti oleh dinas kesehatan, serta masyarakat sebagai konsumen sekiranya harus lebih hati-hati membeli makanan dan jika mendapati pelaku usaha yang nakal dalam hal menjual makanan yang kadaluwarsa dapat melaporkan ke badan pengawas obat dan makanan.

Kata kunci: Perlindungan Hukum, Konsumen Kadaluwarsa

\section{A. Pendahuluan}

Salah satu bentuk kejahatan bisnis yang dilakukan oleh sebagian pengusaha yang tidak bertanggung jawab adalah memproduksi, mengedarkan,menawarkan produk-produk yang berbahaya bagi kesehatan manusia(konsumen). Ulah para pengusaha yang hanya mementingkan keuntungan tanpa memperhatikan akibat bagi konsumen tersebut telah menelan banyak korban. Persaingan global yang terjadi membuat produsen menghalalkan segala cara untuk meraup keuntungan. Akibatnya, berbagai cara dilakukan untuk mengelabui konsumen.Beban konsumen bertambah berat di masa krisis ekonomi ini, denganharga-harga yang tinggi, walaupun kualitasnya masih dipertanyakan. ${ }^{1}$

Adanya penipuan ukuran, berat kg, penggantian tanggal kadaluwarsa, pemalsuan, sertab eredarnya produk-produk luar negeri ilegal di pasaran.Dalam upaya penyelesaian kasus-kasus konsumen tersebut, sering kaliYLKI (Yayasan Lembaga Konsumen Di Indonesia )berhadapan dengan tidak adanya peraturan atau tidak diawasinyapelaksanaan suatu peraturan sehingga pengusaha dapat bersikap masa bodoh. Ini dilakukan para produsen karena persaingan yang begitu hebat danmasyarakat menginginkan harga murah terhadap produk pangan tersebut.

Permasalahan yang dihadapi konsumen Indonesia, seperti juga yang dialami konsumen diNegara-negara berkembang lainnya, tidak hanya sekedar bagaimana memilih barang, tetapi jauh lebih kompleks dari itu yaitu menyangkut kesadaran semua pihak, baik itu pengusaha, pemerintah, maupun konsumen sendiri tentang pentingnya perlindungan konsumen.Beberapa jenis produk pangan pada dasarnya bukanlah produk yang membahayakan, tetapi mudah tercemar atau mengandung racun, yang apabila lalai atau tidak berhati-hati pembuatannya, atau memang lalai untuk tetap mengedarkan, atau sengaja tidak menarik produk pangan yang sudahkadaluwarsa. Kelalaian tersebut erat kaitannya dengan kemajuan dibidang industri yang menggunakan proses produksi dan distribusi barang yang semakin kompleks.

Dalam sistem mekanisme yang demikian, produk yang bukan tergolong produk berbahaya, dapat saja membahayakan keselamatan dan kesehatan konsumen, sehingga diperlukan instrumen yang membuat standar perlindungan hukum yang tinggi dalam proses dan distribusi produk. Kebanyakan orang sekarang ini tidak begitu peduli dengan tanda expired atau tanggal kadaluwarsa dari produk-produk yang akan dibeli atau yang telah dibeli, baik itu berupa produk yang bersifat primer atau pun sekunder.Padahal dengan kita memperhatikan tanda expired atau tanggal kadaluwarsa tersebut kita akan terhindar dari berbagai kerugian, baik itu kerugian material ataupun kerugian batin, seperti daya tahan tubuh kita menjadi menurun dikarenakan keracunan makanan yang sudah kadaluwarsa atau expired, karena kita tidak mengamati dengan jelas kapan produk dari makanan ini sudah tidak layak kita konsumsi lagi atau sudah kadaluwarsa atau expired.

\footnotetext{
${ }^{1}$ Susanti Adi Nugroho, Proses Penyelesaian Sengketa Konsumen Ditinjau dari Hukum Acara serta Kendala Implementasi, (Jakarta: Kencana Prenada Media Group,2008) Hal 6. .
} 
Adapun, ciri-ciri dari produk makanan yang sudah kadaluwarsa atau expired itu terlihat dari bentuk kemasan yang sudah berubah seperti :

a. Kalengnya sudah mengembung.

b. Makanan sudah berubah warna dikarenakan sudah berjamur.

c. Rasanya tidak seperti yang di promosikan di kaleng.

d. Menimbulkan bauk yang tidak sedap ketika di buka.

e. Terus bisa jadi kemasan produknya bukan kemasan terbaru tapi masih dengan model yang lama.

f. Kemasan produk tidak berdebu itu bukanlah suatu jaminan bahwa produk tersebut masih layak atau tidak dikomsumsi. ${ }^{2}$

Perlindungan konsumen di Indonesia berdasar pada Pasal 4 Undang-Undang Nomor Tahun 1999 Tentang Perlindungan Konsumen yang dianggap dapat.memperjuangkan hak-hak konsumen. Dalam Undang-Undang No. 8 Tahun1999 konsumen memiliki hak-hak sebagai berikut adalah :

a. Hak atas kenyamanan, keamanan, dan keselamatan dalam mengkonsumsi barang dan/atau jasa.

b. Hak untuk memilih barang dan /atau jasa serta mendapatkan barang dan/atau jasa tersebut sesuai dengan nilai tukar dan kondisi serta jaminan yang dijanjikan.

c. Hak atas informasi yang benar,jelas, dan jujur mengenai kondisi dan jaminan barang dan/atau jasa.

d. Hak untuk didengar pendapat dan keluhannya atas barang dan/jasa yang digunakan.

e. Hak untuk mendapat advokasi, perlindungan, dan upaya penyelesaiaan sengketa perlindungan konsumen secara patut.

f. Hak untuk mendapat pembinaan dan pendidikan konsumen.

g. Hak untuk diperlakukan atau dilayani secara benar dan jujur serta tidak diskriminatif.

h. Hak untuk mendapatkan kompensasi, ganti rugi dan/atau pengantian, apabila barang dan/atau jasa yang diterimatidak sesuai dengan perjanjian atau tidak sebagaimana mestinya ,

i. Hak-hak yang di atur dalam ketentuan peraturan perundang-undangan lainya. ${ }^{3}$

Keamanan, dan keselamatan dalam konsumen barang atau jasa khususnya terhadap produk pangan kemasan yang kadaluwara. Informasi yang merupakan salah satu hak konsumen didalamnya terkait beberapa hal diantaranya mengenai manfaat kegunaan produk, efek samping penggunaan produk, tanggal kadaluwarsa, isi kandungan yang terdapat dalam produk, serta identitas produsen dari produk tersebut. Informasi tersebut dapat disampaikan secara lisan maupun tertulis baik yang dilakukan dengan cara mencantumkan pada label yang melekat pada kemasan produk, maupun melalui iklan-iklanyang disampaikan produsen baik melalui media cetak maupun media elektronik.

Informasi dapat memberikan dampak yang signifikan untuk meningkatkan efisiensi konsumen dalam memilih produk serta meningkatkan kesetiannya terhadap produk tertentu, sehingga akan memberikan keuntungan bagi perusahaan yang memenuhi kebutuhannya. Dengan demikian,pemenuhan hak ini akan menguntungkan baik konsumen maupun produsen.Kasus-kasus konsumen yang tidak mendapatkan perhatian dari pengusaha dan pemerintah pada perkembangan berikutnya semakin menghilangkan kepekaan pengusaha

\footnotetext{
${ }^{2}$ https://studylibid.com/doc/704539/bab-i-pendahuluan-a.-latar-belakang-masalah-masalah, diaksespada tanggal 23 Juli 2020 pukul 20:20 WIB.

${ }^{3}$ Undang-Undang Nomor 8 Tahun 1999 tentang Perlindungan Konsumen, Pasal 4.
} 
pada masalah konsumen.Melihat persoalan-persoalan yang ada dalam perlindungan konsumen serta aturan yang mengatur yakni Undang-Undang perlindungan konsumen yang seharusnya dapat menjadi benteng sebagai pelindung terhadap palanggaran-pelanggaran atas hak konsumen namun, hal ini belum dapat terealisasi dengan baik.

Ketidakpekaan ini kemudian menjurus pada semakin jauhnya para pengusaha dari norma-norma etika, semakin menipisnya etika bisnis dikalangan pelaku usaha mengakibatkan semakin sulitnya para konsumen untuk mendapatkan hak-haknya. Jika dilihat dari fakta-fakta yang ada, kerugian selalu ada dipihak konsumen maka dari itu ada beberapa hal yang harus diperhatikan yakni :

a. Perbuatan pelaku usaha baik disengaja maupun karena kelalaian dan mengabaikan etika bisnis, ternyata berdampak luas. Dalam kasus semacam itu, kerugian yang diderita konsumen bersifat massal.

b. Dampak yang ditimbulkan pelaku usaha juga dapat bersifat seketika tetapi ada pula yang terlihat dan terasa setelah beberapa waktu.

c. Kalangan yang banyak menjadi korban adalah masyarakat bawah.

d. Pada umumnya mereka tidak mempunyai pilihan lain karena hanya mampu memperoleh barang atau jasa yang dihasilkan dari standar yang tidak memenuhi syarat.

Peredaran makanan kadaluwarsa ini juga dapat ditemui peredarannya dipasar-pasar modern seperti supermarket atau swalayan serta warung-warung kios makanan, seperti yang ditemukan kasus peredaran makanan kemasan yang kadaluwarsa ini beredar diwarung kios Barokah (nama disamarkan), yang didapati oleh seorang pembeli bernama siti haloho yang menemukan beberapa makanan kemasan yani chiki taro yang telah kadaluwarsa. Pedagang kios tersebut berkilah, mengaku tidak mengetahui jika ada barang-barang yang tak layak jual.Pedagang tersebut hanya meminta maaf kepada pembeli dan bersedia mengganti makanan chiki tersebut dengan yang baru. ${ }^{4}$

Dengan, demikian perlindungan hukum terhadap konsumen yang diberikan oleh negara harus segera diimplementasikan dalam kerangka kehidupan ekonomi dalam kehidupan bermasyarakat di Indonesia yang harus pula di imbangi dengan campur tangan atau inisiatif baik dari pelaku usaha dan konsumen.

\section{B. Metode Penelitian Teknik Analisis Data}

Data yang telah diperoleh baik data primer ataupun sekunder diolah dan dianalisis berdasarkan rumusan masalah yang telah diterapkan, sehinggah diharapkan dapat diperoleh gambaran yang jelas tentang kesimpulan atau hasil penelitian yang dicapai. Kemudian disajikan secara deskriptif yaitu menjelaskan, menguraikan, dengan permasalahan yang jelaserat kaitannya dengan penelitian ini guna memberikan pemahaman yang jelas dan terarah yang diperoleh dari hasil penelitian nantinya.

\section{Teknik Pengumpulan Data}

Dalam penelitihan ini, penulis mengumpulan data dan informasi yang dibutuhkan dengan metode:

1. Wawancara

Penulis mengadakan penelitian secara langsung dengan mewawancara kebeberapa toko pelaku usaha yaitu atas nama Toko Tety, TokoNababan, Toko

\footnotetext{
${ }^{4}$ N.H.T. Siahaan, Hukum Konsumen (Perlindungan Konsumen dan Tanggung Jawab Produk), Penerbit Rei 2005 Hal.11
} 
Willem Gulo,Toko Melda, Toko Maluhera dan tanya jawab secara langsung yang dianggap dapat memberikan keterangan yang diperlukan dalam pembahasan objek penelitian

2. Studi pustaka

Selain studi lapangan penulis juga mencari sumber-sumber data melalui studi pussstaka yang bersumber dari buku-buku ,terhadap dokumen perkara serta peraturan-peraturan yang berhubungan dengan penelitian ini. Juga seperti dokumen yang berhubungan dengan masalah yang dibahas serta dari internet.

\section{Pembahasan}

\section{Bentuk Perlindungan Hukum Bagi Konsumen Terhadap Makanan Mie Instan Dalam Kemasan Yang Telah Kadaluwarsa}

Perkembangan sektor ekonomi kususnya perdagangan menghasilkan berbagai jenis barang atau variasi makanan. Tetapi dalam peredaran makanan di Indonesia khususnya mie instan masih menjadi hal yang harus diperhatikan, dimana konsumen sering kali dirugikan dengan pelanggaran yang dilakukan oleh pelaku usaha dengan menjual mie instan yang sudah kadaluwarsa.Persaingan global membuat pelaku usaha menghalalkan segala cara untuk meraup keuntungan salah satunya dengan cara mengedarkan makanan kadaluwarsa sehingga mereka dapat menekan angka kerugian.

Hasil dari penelitian ini adalah Perlindungan hokum bagi konsumen terkait peredaran mie instan kadaluwarsa di Pekanbaru memang perlu diperhatikan dimana banyak konsumen tidak hanya dikota Pekanbaru merasakan kerugian akibat makanan atau minuman kadaluwarsa. Dengan adanya Undang-Undang Nomor 8 Tahun 1999 Tentang Perlindungan Konsumen maka terjaminnya konsumen yang merasa dirugikan serta Badan Penawas Obat dan Makanan dalam tugasnya hanya menjadi media dalam pembinaan bagi pelaku usaha atau produsen yang menjual barang atau makanan yang kadaluwarsa, sedangkan dalam menindak dalam pelaksanaannya yaitu dinas kesehatan. ${ }^{5}$

Tidak hanya memberikan binaan, badan pengawas obat dan makanan dapat memberikan rekomendasi agar ditindak lanjuti oleh dinas kesehatan, serta masyarakat sebagai konsumen sekiranya harus lebih hati -hati dalam membeli makan dan jika mendapati pelaku usaha yang nakal dalam hal menjual makanan yang kadaluwarsa dapat melaporkan kebadan pengawas obat dan makanan. Pentingnya perlindungan bagi konsumen ini agar produk konsumen (Barang Dan/Jasa Konsumen) aman bagi kesehatan atau keamanan jiwa pada umumnya untuk kesejahteraan keluarga atau masyarakat.

Dalam Pasal 1 Ayat 1 Undang -UndangNomor 8 Tahun 1999 menyebutkan bahwa Perlindungan Konsumen Adalah Segala Upaya Untuk Menjamin Adanya Kepastian Hukum Untuk Memberi Perlindungan Kepada Konsumen. Perlindungan konsumen memiliki cakupan yang sangat luas, meliputi perlindungan konsumen terhadap barang dan jasa, yang berawal dari tahap kegiatan untuk mendapatkan barang dan jasa hingga sampai akibat-akibat dari pemakaian barang dan/atau jasa tersebut. ${ }^{6}$

Perlindungan konsumen adalah istilah yang dipakai untuk menggambarkan perlindungan hukum yang diberikan kepada konsumen dalam usahanya untuk memenuhi kebutuhannya dari hal-hal yang merugikan konsumen itu sendiri. Dengan ketersedian kebutuhan sandang(pakaian), papan (pemukiman), serta pangan (makanan) yang cukup dan layak maka perwujudan pembangunan nasional yang berprikemanusiaan,

${ }^{5}$ file://C:/Users/Hp/Downloads/39714-1033-80191-1-10-20180521\%20(2).pdf, diakses pada tanggal 11 Agustus 2020, pukul 13:09 WIB

${ }^{6}$ Undang -Undang Nomor 8 Tahun 1999 Tentang Perlindungan konsumen, Pasal 1 Ayat (1) 
berkeadilan sebagaimana dimanatkan oleh Pancasila dan Undang-Undang Dasar Negara Kesatuan Republik Indonesia Tahun 1945 dapat terwujud.Perlindungan hukum bagi konsumen telah diatur dalam Undang-Undang Nomor 8 Tahun 1999 Tentang Perlindungan Konsumen.Lahirnya undang-undang ini memberikan harapan bagi masyarakat Indonesia, untuk memperoleh perlindungan atas kerugian yang diderita atas transaksi suatu barang dan jasa.Undang-undang perlindungan konsumen ini juga menjamin adanya kepastian hukum bagi konsumen.

Sarana perlindungan hukum dapat dibedakan menjadi dua, yaitu:

a. Perlindungan Hukum Preventif

Perlindungan yang diberikan oleh pemerintah dengan tujuan suntuk mencegah sebelum terjadinya pelanggaran. Hal ini terdapat dalam peraturan perundang-undangan dengan maksud untukmencegah suatu pelanggaran serta memberikan rambu-rambu atau batasan-batasan dalam melakukan suatu kewajiban.

b. Perlindungan Hukum Represif

Perlindungan hukum represif merupakan perlindungan akhir berupa sanksi seperti denda, penjara, dan hukuman tambahan yang diberikan apabila sudah terjadi sengketa atau telah dilakukan suatu pelanggaran.Dalam pasal 1 ayat 2 disebutkan pengertian konsumen yaitu dimana setiap orang pemakai,pengguna barang dan atau jasa yang tersedia dimasyarakat untuk kepentngan atau kebutuhan diri sendiri maupun orang banyak.Pemenuhan penggunaan barang dan atau jasa dilakukan oleh pelaku usaha.pelaku usaha ialah setiap orang atau badan usaha yang berbentuk hukum melakukan kegiatan di wilayah republik. Indonesia menyelenggarakan kegiatan usaha dalam bidang ekonomi.Konsumen sebagai pengguna barang atau jasa sering kali mendapati barang yang dibeli dari pelaku usaha atau produsen tidak layak konsumsi atau pakai salah satunya yaitu mie instan yang sering dijual dengan keadaan kadaluwarsa.

Dimana menyebabkan konsumen merasa dirugikan, produsen yang menjual mie instan sendiri sebagai pelaku usaha hendaknya harus lebih memeriksa barang yang diperdagangkan dan memusanahkan barang yang kadaluwarsa agar tidak merugikan konsumen.Kerugian yang didapat konsumen akibat tidak bertangggung jawabnya produsen makanan mie instan yang kadaluwarsa dapat diklarifikasi dalam:

1. Kerugian materiil dimana berupa makanan yang dibeli yaitu mie instan

2. Kerugian imateriil yaitu dalam membahayakan kesehatan atau jiwa konsumen yang tidak menyadari mie instan kadaluwarsa

Pasal 8 Ayat 3 Undang-Undang Nomor 8 Tahun 1999 Tentang Perlindungan Konsumen menjelaskan perbuatan yang dilarang bagi pelaku usaha yaitu pelaku usaha dilarang memperdagangkan barang yang rusak, cacat atau bekas dan tercemar ,dengan atau tanpa memberikan informasi secara lengkap dan benar. ${ }^{7}$

Meskipun sudah diatur mengenai larangan terhadap pelaku usaha agar menarik makanannya khususnya mie instan dalam penjualannya Akan tetapi pada

\footnotetext{
${ }^{7}$ Undang -UndangNomor 8 Tahun 1999 Tentang Perlindungan konsumen, Pasal 8 Ayat (3)
} 
kenyataannya,larangan tersebut tidak diperhatikan oleh pelaku usaha dan sering kali merugikan konsumen serta tetap menjual barang yang sudah kadaluwarsa Walaupun sudah ada aturan yang melarangnya akan tetapi tidak ditindak tegas bahkan cendrung diberikan toleransi. Dimana Konsumen untuk memperjuangkan hak-hak ganti rugi dirasa masih rendah, serta pihak produsen menghindar dari tanggungjawab terhadap kerugian konsumen berkaitan dengan makananmie instan kadaluwarsa.

Oleh karena itu gugatan konsumen terhadap produsen yang telah melakukan perbuatan melawan hukum, yaitu menjual produk yang tidak aman yang menyebabkan timbulnya kerugian bagi konsumen serta adanya unsur kesalahan yang dilakukan pelaku usaha berdasarkan Undang-Undang Nomor 8 Tahun 1999 tentang Perlindungan Konsumen karena adanya prinsip praduga bersalah dan tanggung jawab produk Tidak hanya dalam UUPK tetapi Peraturan Pemerintah Nomor 28 Tahun 2004 Tentang Keamanan,Mutu, dan Gizi Pangan utamanya dalam Pasal 47 ayat (2) yang dijelaskan bahwa tindakan administratif berupa peringatan secara tertulis; larangan mengedarkan untuk sementara waktu dan/atau perintah menarik produk pangan dari peredaran; pemusnahan pangan, jika terbukti membahayakan kesehatan dan jiwa manusia; penghentian produksi untuk sementara waktu pengenaan denda paling tinggi sebesar Rp. 50.000.00o,oo (lima puluh juta rupiah); dan/atau pencabutan izin produksi, izin usaha, persetujuan pendaftaran atau sertifikat produksi pangan industri rumah tangga. Para pelanggarnya juga dapat dikenakan sanksi Pidana sesuai pada Pasal 62 ayat (1) Undang-UndangNomor 8 Tahun 1999 Tentang Perlindungan Konsumen.

Pasal 2 UU PK adalah tentang tujuan perlindungan konsumen yang akan menyinggung tentang menciptkan sistem perlindungan konsumen yang mengandung unsur kepastian hukum dan keterbukaan informasi serta akses untuk mendapatkan informasi. Meningkatkan kualitas barang dan/jasa ,kesehatan,keyamanan, keamanan ,dan keselamatan konsumen.

\section{Tanggung Jawab Pelaku Usaha bagi konsumen terhadap makanan Mie Instan yang} dalam kemasan telah kadaluwarsa

Pelaku usaha bertanggung jawab memberikan ganti rugi atas kerusakan, pencemaran,dan atau kerugian konsumen akibat mengkonsumsi barang dan atau jasa yang dihasilkan atau diperdagangakan. Bagi pelaku usaha yang melakukan pelanggaran ketentuan produk makanan kadaluwarsa (tidak mencantumkan tanggal kadaluwarsa secara jelas), maka dapat diberikan sanksi hukum berupa sanksi adminitratif atau sanksi hukum lainya sesuai dengan ketentuan perundang-undangan yang berlaku. Sementara bagi pelaku usaha yang mengimpor atau mengedarkan produk makanan kaluwarsa maka dapat diberikan sanksi hukum berupa hukuman kurungan atau denda sebagaimana ditetapkan dalam Pasal 2 ayat (1) Undang-undang Bahan Berbahaya Stb.1949 Nomor 377, (pasal 5 ayat 1 dan ayat 2 peraturan Menteri Kesehatan Republik Indonesia Nomor 180/MEN.KES/PER/IV/1985). ${ }^{8}$

Undang -undang perlindungan konsumen melalui ketentuan Pasal 19 ayat (1) hanya menyebutkan pihak pelaku usaha yang bertanggungjawab. Tidak diberikan penjelasan lebih rinci pelaku usaha siapa yang dimaksud guna kepastian hukum yang seyogyanya ada kejalsan siapa pelaku usaha yang harus bertanggungjawab atas kerugian konsumen dalam hal produk makanan kadaluwarsa.

Memperhatikan substansi Pasal 19 Undang-Undang Perlindungan Konsumen, bahwa tanggung jawab pelaku usaha meliputi:

\footnotetext{
${ }^{8}$ file:///C:/Users/Hp/Downloads/13164-1-24423-1-10-20150512\%20(1).pdf, diakses pada tanggal 18 Agustus 2020 pukul 15:59 WIB
} 
1. Tanggung jawab ganti kerugian atas kerusakan, pencemaran, dan atau kerugian konsumen akibat mengkonsumsi barang dan atau jasa yang dihasilkan atau diperdagangkan.

2. Ganti rugi sebagaimana dimaksud pada ayat (1) dapat berupa pengembalian uang atau pengantian barang dan/atau jasa sejenis atau setara nilainya, atau perawatan kesehatan dan /atau pemberian santunan yang sesuai dengan ketentuan peraturan perundang-undangan yang berlaku.

3. Pemberian ganti rugi dilaksanakan dalam tenggang waktu 7 ( tujuh) hari setelah tanggal transaksi

4. Pemberian ganti rugi sebagaimana dimaksud pada ayat (1) dan ayat (2) tidak menghapuskan kemungkinan adanya tuntutan pidana berdasarkan pembuktian lebih lanjut mengenai adanya unsur kesalahan.

5. Tidak berlaku apabila pelaku usaha dapat membuktikan bahwa kesalahan tersebut merupakan kesalahan konsumen. ${ }^{9}$

Berdasarkan hal tersebut, maka adanya produk barang dan/atau jasa yang berupa makanan kadaluwarsa bukan merupakan satu-satunya dasar pertanggungjawaban pelaku usaha. Hal ini berarti bahwa tanggung jawab pelaku usaha meliputi segala kerugian yang dialami berkaitan dengan konsumsi dan perdagangan barang dan/atau jasa di masyarakat.

Perlindungan konsumen merupakan tanggung jawab semua pihak yaitu pemerintah,pelaku usaha,organisasi konsumendan konsumen itu sendiri.pemerintah bertindak mengayomi masyarakat dan juga membina pelaku usaha dalam meningkatkan kemajuan industri dan perekonomian negara.Bentuk perlindungan konsumen yang diberikan adalah dengan mengeluarkan undang-undang, tidak kalah pentingnya adalah melakukan pengawasan pada penerapan peraturan , peratutan-peraturan pemerintah, atau penerbitan standar mutu barang ${ }^{10}$

\section{D.Kesimpulan}

1. Perlindungan Hukum bagi Konsumen Menurut Pasal 8 Ayat (1) huruf g Undang-undang Nomor 8 Tahun 1999 Tentang perlindungan konsumen yaitu tidak mencantumkan tanggal kadaluwarsa atau jangka waktu penggunaan/pemanfaatan yang paling baik atas barang tertentu, konsumen dapat ditempuh melalui pengadilan atau di luar pengadilan berdasarkan pilihan sukarela para pihak yang bersengketa. Pada setiap tahap diusahakan untuk menggunakan penyelesaian damai oleh kedua belah pihak yang bersangkutan baik secara kekeluargaan. Yang dimaksud dengan penyelesaian secara damai atau kekeluargan adalah penyelesaian yang dilakukan oleh kedua belah pihak yang bersengketa (pelaku usaha dan konsumen) tanpa melalui pengadilan atau badan penyelesaian sengketa konsumen dan tidak bertentangan dengan undang-undang ini. Dan apabila pelaku usaha tidak dapat melakukan penyelesaian diluar pengadilan maka akan dilakukan dalam pengadilan dan ancaman Pidana bagi pelaku usaha yang melanggar larangan tersebut Berdasarkan UUPK Peraturan Pemerintah Nomor 28 Tahun 2004

\footnotetext{
${ }^{9}$ Undang -UndangNomor 8 Tahun 1999 Tentang Perlindungan konsumen,Pasal 19

${ }^{10}$ Ahmad Miru, dan Sutarman Yudo, Hukum Perlindungan Konsumen ,Cetakan Kedua, Jakarta: Raja Grafindo Persada, 2004
} 
Tentang Keamanan,Mutu, dan Gizi Pangan utamanya pasal 47 ayat (2)atau pidana denda paling banyak Rp. 50.00o.ooo,oo (lima puluh juta rupiah) dan bisa juga dengan pencabutan hak izin usaha.

2. Bentuk Tanggung Jawab Pelaku Usaha atas Makanan Kadaluwarsa Berdasarkan Pasal 19 Ayat 1 dan 2 Undang-undang Nomor 8 Tahun 1999 tentang Perlindungan Konsumen, diatur bahwa Pelaku Usaha bertanggung jawab memberikan ganti rugi atau kerusakan, pencemaran, dan atau kerugian konsumen, akibat mengkonsumsi barang dan atau jasa yang dihasilkan atau diperdagangkan. Ganti rugi yang dimaksud dapat berupa pengembalian uang atau penggantian barang dan atau jasa yang sejenis atau setara nilainya, sesuai dengan ketentuan perundang-undangan yang berlaku. Bentuk tanggung jawab pada Kasus di Toko Willem ialah, Pelaku usaha (Penjual) kepada Saudara Ami surbakti adalah mengganti produk ( Mie Instan ) yang sejenis dengan keadaan yang baru dan tidak lewat tanggal dan memberi biaya perobatan kepada ibu ami surbakti sampai keadaan sembuh.

\section{Saran}

Toko Swalayan tersebut selaku penjual yang memasarkan hasil dari suatu produk Barang dari Produsen untuk dijual ke para konsumen produk tersebut, seharusnya memeriksa pelaku usaha terlebih dahulu kondisi barang tersebut. Atau hal ini dapat mengurangi terjadinya kerugian konsumen.

Pelaku Usaha dan konsumen harus lebih mengerti apa hak dan kewajibanya dari masingmasing,sesuai dengan ketentuan atau Dasar Hukum dari Undang-Undang Nomor 8 Tahun 1999 Tentang Perlindungan Konsumen karena masih sangat banyak peristiwa dari konsumen yang lebih dirugikan dan pelaku usaha lebih diuntungkan.

\section{Daftar Pustaka}

Ahmadi Miru \& Sutarman Yodo, Hukum Perlindungan Kosumen, Jakarta: PT Raja Grafindo Persada, 2005

Adi Nugroho Susanti, Penyelesaian Sengketa Konsumen Ditinjau Dari Hukum Acara Serta Kendala Implementasi, Jakarta: kencana Prenada Media Group, 2008

Gunawan Widjaja dan Ahmad Yani, Hukum perlindungan Konsumen, Gramedia Pustaka Utama, Jakarta 2000

M. Sadar, dkk, Hukum Perlindungan Konsumen di Indonesia, Akademia, Jakarta,2012

Sidabalok, Janus, Hukum Perlindungan Konsumen di Indonesia, Citra Aditya,2010

Siahaan,N.H.T, Perlindungan Konsumen dan Tanggungjawab Produk, Jakarta : Panta Rei, 2005

Sunggono Bambang, Metode Penelitian Hukum, Jakarta: Rajawali Pers, 2015

\section{Peraturan Perundang-undangan}

Republik Indonesia, Undang-Undang Nomor 8 Tahun 1999 Tentang Perlindungan Konsumen Undang - Undang, Nomor 18 Tahun 2012 tentang pangan

Kitab Undang-Undang Hukum Perdata,Cet.1 2015, Surabaya : Sinarsindo Utama

\section{Internet}

https://id.wikipedia.org/wiki/Perlindungan_konsumen diakses pada Hari sabtu,2 juni 2020 file://C:/Users/Hp/Downloads/13164-1-24423-1-10-20150512\%20(1).pdf,diakses pada tanggal 18 Agustus 2020 pukul 15:59 WIB 
Nommensen Journal of Legal Opinion (NJLO)

Jurnal Magister Hukum Program Pascasarjana Universitas HKBP Nommensen

Volume o2 Nomor o1 Januari 2021 Halaman. 93-102 e-ISSN: 2723-164X p-ISSN: 2722-9858

http://ejournal.uhn.ac.id/index.php/opinion

https://istanaumkm.pom.go.id/default/penerapan-label-pangan, diakses pada tanggal 6 Agustus 2020, pukul 20.30 WIB. 